\title{
Call to scrap licences for travel to Cuba
}

[WASHINGTON] Stringent travel rules are effectively blocking scientific collaboration between the United States and Cuba, and should be applied more fairly or scrapped altogether, according to a report from the American Association for the Advancement of Science (AAAS).

A meeting held in Washington DC last week to discuss the report was told of sometimes "arbitrary and capricious" granting of licences to spend money on travel to Cuba by the Department of the Treasury's Office of Foreign Assets Control (OFAC).

Despite its struggling economy, Cuba is the most scientifically advanced of the Caribbean islands, say AAAS officials. For example, Fidel Castro's communist government has invested $\$ 1$ billion since 1980 in a well-equipped and integrated biotechnology research programme.

According to Richard Getzinger, head of international programmes at the AAAS, products from the programme already yield exports from Cuba worth $\$ 125$ million a year. The island also has internationally supported research efforts in ecology and marine biology.

But more traditional, university-based scientific disciplines, such as physics and chemistry, have collapsed since losing support from the former Soviet Union. "The crisis in physical sciences in Cuba is extreme," says Irving Lerch, head of international affairs at the American Physical Society.

Under its economic embargo of Cuba, the United States does not allow its own citizens to spend money on travel to Cuba, and does not allow Cubans employed by the

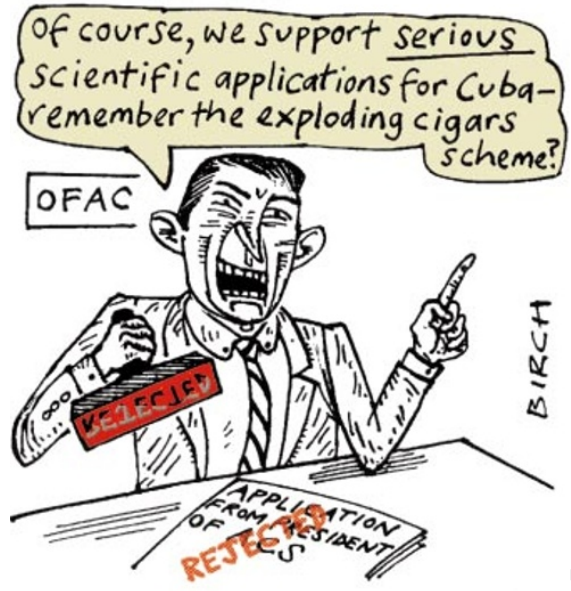

government — as most scientists are - to visit the United States. In theory, scientific researchers are exempt from both regulations, but many encounter problems when applying for permission to travel.

Luis Montero, for example, a chemistry professor at the University of Havana, has applied for an entry visa to the United States almost every year since 1990 to attend the same quantum chemistry meeting at Sanibel Island, Florida. His applications were granted in 1993 and 1996, but refused in 1990, 1991, 1994 and 1997.

In another case, OFAC recently turned down a request from Paul Walters, president of the American Chemical Society (ACS), to visit Cuba on a fact-finding mission. Walters had been invited by the president of the Cuban chemical society.

Asked at the meeting about the rejection, Clara David, a senior licensing officer at

\section{Irish scientists face another budget blow}

[MUNICH] Irish scientists were last week told that there is after all no money for new basic research projects in the 1998 budget of Forbairt, the government research agency in the Republic of Ireland. This comes despite a call for proposals last December and the completion of the grants review procedure.

It is the second time in five years that scientists have responded to a call for proposals only to find that there was no money to pay for successful applications (see Nature 364, 662; 1993).

Forbairt's basic research grant review committee was informally told last year that IE6 million (US\$8 million) would be available. But it was given only enough cash to continue existing commitments. A spokesman for the Irish Office of Science and Technology, which oversees the agency, says the office will try to free cash from other sources to honour some of the projects the review committee approved for funding.
But David Fegan, a physicist who is a member of the grants review committee, says basic research seems to have lost its permanent home in a proposed government reorganization. The government, which came to power last autumn, wants to merge Forbairt with the Industrial Training Authority and the Irish Export Board into a new agency called Enterprise Ireland.

The new body will be responsible for the development of industry. Basic research would fit uneasily into its remit, but the government has not indicated where it would like basic research to be handled. One possibility is that it will return to the ministry of education. The ministry was last year given I£5 million for research, yet could find no mechanism for allocating it. Researchers speculate that the Office of Science and Technology is relying on this money being made available for Forbairt's basic research programme.
OFAC, said: "Maybe the application was too general in its approach." John Malin, head of the ACS international section, says that he and Walters are now reapplying.

Some scientists who have had problems are incensed that the regulations require officials at OFAC, who have no scientific qualifications, to assess the legitimacy of proposed research. "Their level of disingenuousness continues to amaze me," says Ross MacPhee, a palaeontologist at the American Museum of Natural History in New York.

He says that several colleagues have had permission to go to Cuba denied on the grounds that they "can't just go there and look around". But just looking around, he points out, "is pretty much what a palaeontologist does!”

Michael Ranneberger, coordinator for Cuban affairs at the US State Department, says Cuba's human rights record is the reason for the embargo and the regulations. Most requests for travel in both directions are granted, he says, and "a great number of scientific exchanges have taken place”.

Ranneberger says more than 80 per cent of Cuban researchers applying for visas to travel to the United States last year were successful, and that the 600 licences granted to US researchers to travel to Cuba last year constitute a majority of applications. He could not say how many US researchers were refused permission to travel.

The AAAS's human rights office is attempting to extract this information from the government using the Freedom of Information Act. Its report calls for an end to the licensing requirement, adding that, if it must continue, OFAC should ask scientific societies for help in assessing applications.

Kate Martin, a civil liberties lawyer, thinks researchers denied permission to pay for travel to Cuba could sue the government for breach of the First Amendment to the US Constitution, which guarantees freedom of speech. Because they need to travel in order to exchange ideas, "scientists have a stronger First Amendment right to travel than the rest of us," she says.

But some US researchers who have worked in Cuba say the regulations do not interfere with the sufficiently determined collaborator. Michael Smith, director of the Caribbean Biodiversity Program, says he held a briefing for OFAC officials early on, and has had no trouble getting permission to travel since. "We've had hundreds of licences [to visit Cuba] and only a handful of problems," he says. "We've also had hundreds of Cubans over here." Smith suggests that energy should be spent on proposing projects and making them work, rather than battering away at a government policy that is unlikely to change.

Colin Macilwain 